\title{
Volatile Flavor Components of Dried Bonito (Katsuobushi). I. On Basic, Acidic and Weak Acidic Fractions
}

\author{
Izumi Yajima, Mikio Nakamura, Hidemasa SaKakibara, \\ Tetsuya YanaI and Kazuo HayashI
}

Kawasaki Research Laboratories, T. Hasegawa Co., 335-Kariyado, Nakahara-ku, Kawasaki 211, Japan

Received February 24, 1981

\begin{abstract}
The aqueous extract of dried bonito (Katsuobushi) was distilled by using a thin film evaporator. The resulting distillate was extracted with diethyl ether, and the extract was separated into basic, acidic, weak acidic, and neutral fractions.

The basic, acidic, and weak acidic fractions were analyzed by gas chromatography and gas chromatography-mass spectrometry.

Seventy-four compounds, including 24 acids, 24 phenols, 8 pyridines, 12 pyrazines, 3 thiazoles, and 3 other compounds were identified. Thirty-six of these compounds were newly identified as volatile flavor compounds of Katsuobushi.
\end{abstract}

Katsuobushi, a traditionally used flavor enhancer of Japanese foods, is a complex of flavor compounds induced by a variety of preparation processes including boiling, sun drying, smoking and mold culturing.

Nishibori et al. ${ }^{1 \sim 7)}$ pointed out that phenolic volatiles derived from wood smoke were important to Katsuobushi flavor; 2,6-dimethoxyphenolic derivatives being especially important. Yamanishi et al ${ }^{8,9)}$ reported that about 200 compounds were detected by gasliquid chromatography from Katsuobushi extract and suggested that the most important flavor contributors were 1,2-dimethoxy4-methylbenzene, cis,cis-1,5,8-undecatrien-3ol and cyclotene. In a most recent paper, Hirayama et al. ${ }^{10)}$ reported that $c i s$-4-heptenal contributed to the characteristic flavor of Katsuobushi.

In this manner, several valuable compounds have been identified through many studies on the volatile flavor compounds of Katsuobushi.

However, the mixing of these compounds has not been found sufficient to reproduce the true flavor and aroma of Katsuobushi, because Katsuobushi has some very delicate and complex aroma characteristics.

This investigation was undertaken to iden- tify the additional volatile flavor components of Katsuobushi.

\section{MATERIALS AND METHODS}

Materials. Katsuobushi, produced in the Makurazaki district of Kagoshima prefecture in Japan, was used immediately after shaving.

Methods.

a) Collection of volatile flavor compounds. Ten kilograms of Katsuobushi shavings were added to $150 \mathrm{~kg}$ of boiling water and the temperature was maintained for three minutes. After rapidly cooling and removing the residual Katsuobushi by filtering, the resulting solution was distilled under reduced pressure $\left(28^{\circ} \mathrm{C} / 10 \mathrm{mmHg}\right)$ by using a thin film evaporator connected to a receiver and three cold traps, the first trap being cooled by dry iceacetone and the other two by liquid nitrogen. Fourty kilograms of distillate containing the volatile flavor compounds were obtained. The distilate was then saturated with sodium chloride and extracted three times with 4 liters of redistilled diethyl ether. The ether solution was dried over anbydrous sodium sulfate and concentrated to one liter by using a Vigreoux column. From this flavor concentrate, having the characteristic flavor of Katsuobushi, $100 \mathrm{ml}$ were further concentrated to approximately $100 \mathrm{mg}$ for gas chromatographic analysis and the remaining $900 \mathrm{ml}$ were fractionated by the following method.

b) Fractionation of flavor concentrate. As shown in Fig. 1, the flavor concentrate was separated into basic, 


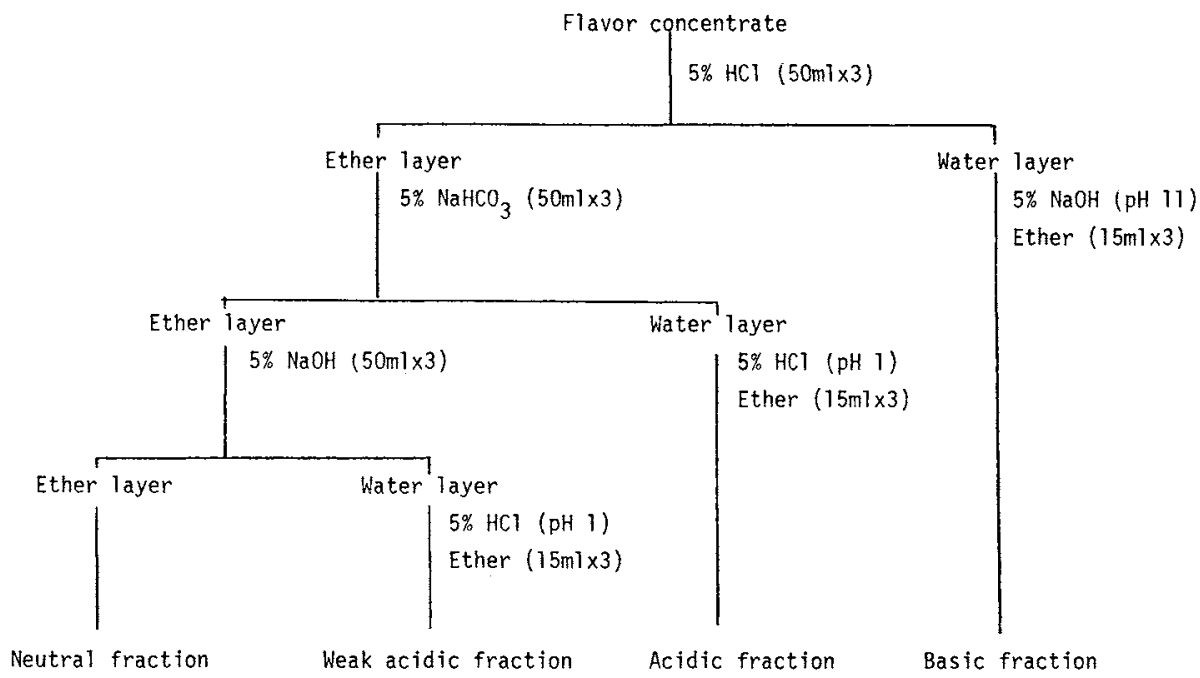

FIG. 1. Fractionation of the Flavor Concentrate of Katsuobushi.

acidic, weak acidic, and neutral fractions, which were concentrated to approximately $20 \mathrm{mg}, 15 \mathrm{mg}, 300 \mathrm{mg}$, and $300 \mathrm{mg}$, respectively. Among them, basic, acidic, and weak acidic fractions were analyzed by gas chromatography (GC) and gas chromatography-mass spectrometry (GCMS), with the exception of the acidic fraction which was analyzed after methylation.

c) GC-conditions. A Hitachi Model 163 gas chromatograph, equipped with an effluent splitter $(1: 2)$, which was placed between the end of the GC column and the two detectors, was used. The effluent was separated by the splitter at a splitting ratio 1 to 2 , the first portion being passed to a flame ionization detector (FID) circuit and the second portion to a flame photometric detector (FPD) circuit, the latter having a high sensitivity to sulfurcontaining compounds. This GC instrument was fitted with a $0.28 \mathrm{~mm}$ i.d. $\times 50 \mathrm{~m}$ glass SCOT column coated with PEG $20 \mathrm{M}$. The operating conditions were; injection port and detector temperatures, $250^{\circ} \mathrm{C}$; column temperature, programmed from $60^{\circ} \mathrm{C}$ to $190^{\circ} \mathrm{C}$ at $3^{\circ} \mathrm{C} / \mathrm{min}$; carrier gas $\left(\mathrm{N}_{2}\right)$ flow, $1 \mathrm{ml} / \mathrm{min}$.

d) Sniffing evaluation of flavor compounds emitted at each peak on the gas chromatograms. The organoleptic evaluation was accomplished by sniffing at the exist port of a Hitachi Model 163 gas chromatograph fitted with an effluent splitter, while samples were eluted. The effluent was proportioned by the splitter at a ratio of 1 to 10 , the first portion being passed to an FID circuit and the second portion to the exit port which was heated to $180^{\circ} \mathrm{C}$ by a small heater to prevent condensation. The gas chromatograph was equipped with a $0.5 \mathrm{~mm}$ i.d. $\times 70 \mathrm{~m}$ glass SCOT column coated with PEG $20 \mathrm{M}$. Other operating conditions were the same as above.

e) GC-MS conditions. A Hitachi Model RMU-6MG mass spectrometer was used. A glass SCOT column $(0.28$ mm i.d. $\times 50 \mathrm{~m}$ ) coated with PEG $20 \mathrm{M}$ was used. The operating parameters were as follows; column temperature, programmed from $60^{\circ} \mathrm{C}$ to $180^{\circ} \mathrm{C}$ at $2^{\circ} \mathrm{C} / \mathrm{min}$; carrier gas, helium; ionizing voltage, $70 \mathrm{eV}$; accelerating voltage, $3200 \mathrm{~V}$; ion source temperature, $200^{\circ} \mathrm{C}$.

\section{RESULTS AND DISCUSSION}

Table I lists the approximate yield of each fraction of the flavor concentrate from Katsuobushi. The total amount of the flavor compounds was $320 \mathrm{mg}$, which was equivalent to $32 \mathrm{ppm}$ of the raw materials used. It was found that the weak acidic and neutral fractions amounted to $95 \%$ of the total flavor compounds and the basic and acidic fractions were small, being only $5 \%$ in quantity.

Table I. Yields of Flavor Compounds OBTAINED FROM "KaTSUOBUSHI"

\begin{tabular}{|c|c|c|}
\hline Fractions & & $w t \%$ \\
\hline Total & $320 \mathrm{mg}(32 \mathrm{ppm})^{*}$ & 100 \\
\hline Basic & & 3 \\
\hline Acidic & & 2 \\
\hline Weak acidic & & 52 \\
\hline Neutral & & 43 \\
\hline
\end{tabular}

* Yield was calculated using the following equation: Yield $(\mathrm{mg})=$ weight $(\mathrm{mg}) \times[100-($ Solvent peak area $\%$ on gas chromatogram $) / 100]$. 
Figure 2 shows the gas chromatogram of the flavor concentrate of Katsuobushi. The chromatogram indicates the presence of over 160 compounds. Of these, the basic, acidic, and weak acidic compounds were analyzed by $\mathrm{GC}$ and GC-MS. Each substance was identified by comparing and matching their mass spectra and $\mathrm{GC}$ retention times with those of authentic compounds.

\section{1) Basic fraction}

The basic fraction, though being very small in quantity, was found to be particularly interesting in having a strong roasted and fishlike aroma.

Figure 3-A shows a gas chromatogram of the basic fraction when using FID as a detector. Peak No. 62 is one of the larger quantity compounds in the basic fraction. This compounds was found to have a fish-like aroma and provided one of the characteristic elements of Katsuobushi flavor sniffed at the exit port of the gas chromatograph. In order to identify this unknown compounds corresponding to peak No. 62, it was separated from other compounds by using a gas chromatograph with a $3 \mathrm{~mm}$ i.d. $\times 4 \mathrm{~m}$ length glass column packed with PEG-20 M, and then analyzed by GC-MS and infrared spectrometry. The infrared spectrum was obtained by JASCO IRA-2, using an ultramicro capacity cell and a reflecting beam condenser. This unknown compound indicated the following mass spectra and infrared spectrum: MS $m / z$ $(\%) ; 109\left(\mathrm{M}^{+} 100\right), 94(15), 79(13), 66(56), 51$ (14), 50 (9), 39 (59), 38 (15). IR cm ${ }^{-1} ; 1585 \mathrm{~m}$, $1580 \mathrm{~s}, 1480 \mathrm{~s}, 1460 \mathrm{~m}, 1425 \mathrm{~s}, 1283 \mathrm{~s}, 1270 \mathrm{~s}$, $1190 \mathrm{~m}, 1127 \mathrm{w}, 1100 \mathrm{w}, 1055 \mathrm{~m}, 1022 \mathrm{~s}, 800 \mathrm{w}$, $790 \mathrm{w}, 700 \mathrm{w}$. These spectra indicated that this compound was probably 3-methoxypyridine. This was further confirmed by comparing and matching the spectra and $\mathrm{GC}$ retention time with those of 3-methoxypyridine synthesized from 3-hydroxypyridine and diazomethane in our laboratory. This 3-methoxypyridine had previously been found in black tea ${ }^{11)}$ and heated soy sauce, ${ }^{12)}$ but was found for the first time in Katsuobushi.

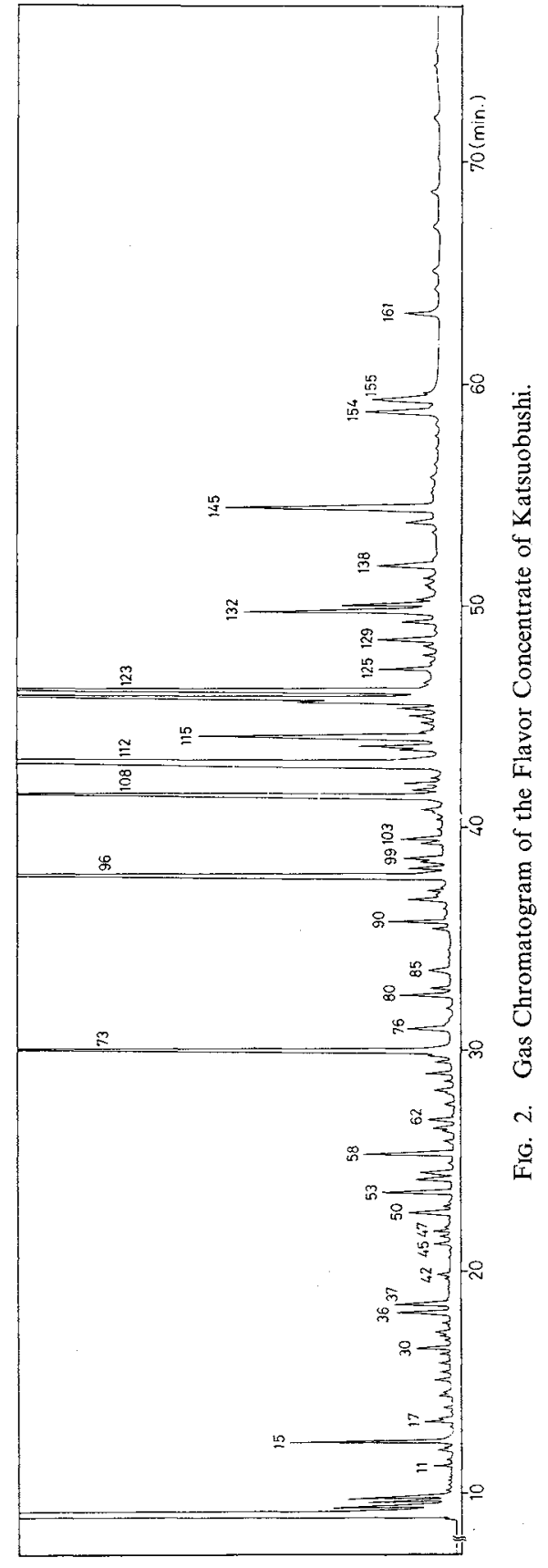




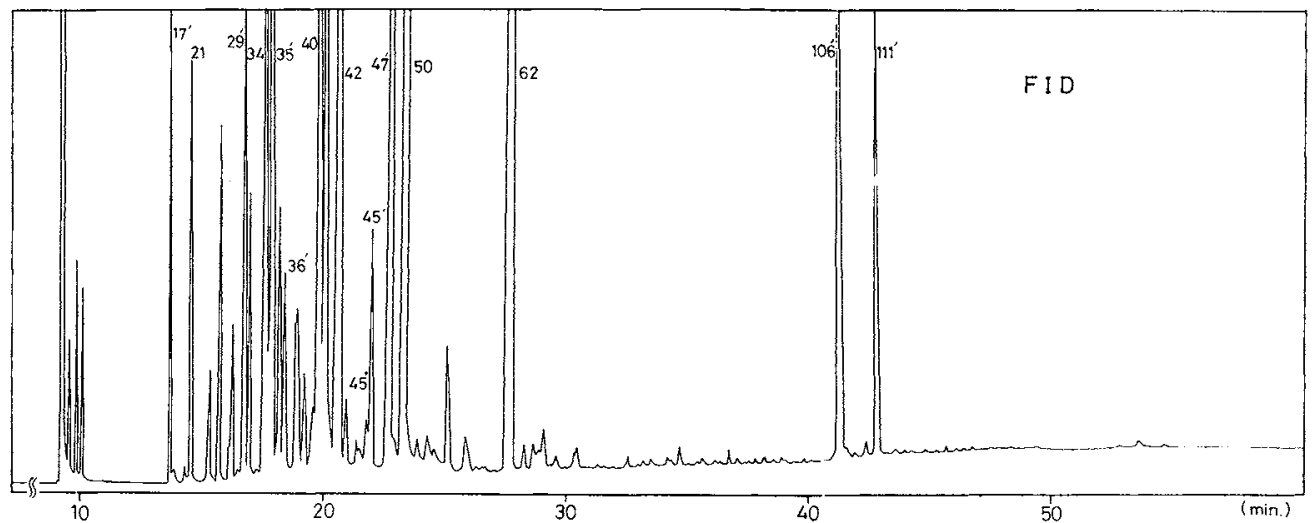

Fig. 3-A. Gas Chromatogram of the Basic Fraction of Katsuobushi when FID is Used as a Detector.

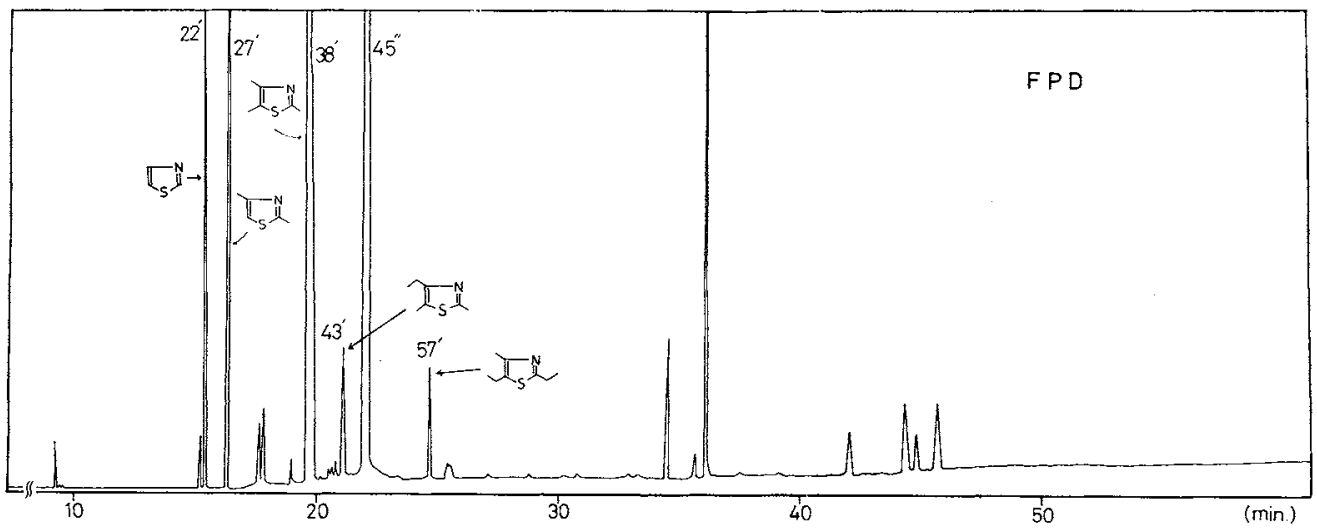

FIG. 3-B. Gas Chromatogram of the Basic Fraction of Katsuobushi when FPD is Used as a Detector.

On the presumption that the sulfurcontaining compounds in the basic fraction were important, we conducted a gas chromatographic analysis, using FPD as the detector, to isolate the existence of these compounds.

The resulting chromatogram is shown in Fig. 3-B. It indicates the presence of more than 30 compounds, of which three sulfur containing substances, namely, thiazole (peak No. 22'), 2,4-dimethylthiazole (peak No. 27'), and 2,4,5-trimethylthiazole (peak No. 38'), were identified. The thiazole, which has a nutty aroma, has been known to exist in roasted peanuts, ${ }^{13)}$ cooked beef ${ }^{14)}$ etc., the 2,4-dimethylthiazole, which has a green nutty aroma, has been known to exist in coffee, ${ }^{15}$ ) black tea, ${ }^{11)}$ cooked beef, ${ }^{14)}$ etc. and 2,4,5-trimethylthiazole, which also has a nutty aro- ma, has been known to exist in coffee, ${ }^{15}$ ) black tea, ${ }^{11)}$ and cooked beef ${ }^{14)}$ etc. These substances were found for the first time in Katsuobushi. The compounds corresponding to peak No. $43^{\prime}$ and peak No. $57^{\prime}$ were tentatively identified by GC retention times as 2,5-dimethyl-4-ethylthiazole and 2,5-diethyl-4methylthiazole, respectively. Likewise, peak No. $45^{\prime \prime}\left(M_{w}\right.$ 141) was assumed to be a thiazole derivative but could not be positively identified.

Table II shows the compounds identified from the basic fraction. Eight of these compounds were identified as pyrizine compounds, of which seven were found in Katsuobushi for the first time. Likewise, 12 compounds were identified as pyrazine compounds. Among them, seven were newly found in Katsuobushi, 
TABle II. Volatile Compounds Identified FROM THE BASIC FRACTION

\begin{tabular}{|c|c|c|}
\hline Peak No. & Compounds & Amounts \\
\hline & Pyridines & \\
\hline $17^{b}$ & Pyridine & + \\
\hline $21 *$ & 2-Methylpyridine & + \\
\hline $28^{*}$ & 2-Ethylpyridine & + \\
\hline $29^{\prime *}$ & 3-Methylpyridine & + \\
\hline $30^{\prime *}$ & 4-Methylpyridine & + \\
\hline $38^{*}$ & 3-Ethylpyridine & + \\
\hline $47^{\prime *}$ & 3-Vinylpyridine & + \\
\hline \multirow[t]{2}{*}{$62^{*}$} & 3-Methoxypyridine & $+t+$ \\
\hline & yrazines & \\
\hline $23^{*}$ & Pyrazine & + \\
\hline $24^{\prime *}$ & 2-Methylpyrazine & + \\
\hline 34 & 2,5-Dimethylpyrazine & + \\
\hline 35 & 2,6-Dimethylpyrazine & ++ \\
\hline $35^{\prime *}$ & 2-Ethylpyrazine & + \\
\hline $36^{\prime *}$ & 2,3-Dimethylpyrazine & + \\
\hline 40 & 2-Ethyl-6-methylpyrazine & ++ \\
\hline 41 & 2-Ethyl-5-methylpyrazine & + \\
\hline 42 & $2,3,5$-Trimethylpyrazine & +++ \\
\hline $45^{\prime *}$ & $\begin{array}{l}\text { 2,5-Dimethyl-3-ethyl- } \\
\text { pyrazine }\end{array}$ & + \\
\hline $47^{\prime *}$ & $\begin{array}{l}\text { 2,6-Dimethyl-3-ethyl- } \\
\text { pyrazine }\end{array}$ & ++ \\
\hline \multirow[t]{2}{*}{$50^{\prime *}$} & Tetramethylpyrazine & +++ \\
\hline & rhiazoles & \\
\hline $22^{\prime *}$ & Thiazole & + \\
\hline $27^{*} *$ & 2,4-Dimethylthiazole & + \\
\hline $38^{\prime *}$ & $2,4,5$-Trimethylthiazole & + \\
\hline $43^{\prime *}$ & $\begin{array}{l}\text { 2,5-Dimethyl-4-ethyl- } \\
\text { thiazole }^{a}\end{array}$ & + \\
\hline \multirow[t]{2}{*}{$57^{*}$} & $\begin{array}{l}\text { 2,5-Diethyl-4-methyl- } \\
\text { thiazole }^{a}\end{array}$ & + \\
\hline & Dthers & \\
\hline $106^{\prime}$ & Quinoline & + \\
\hline $111^{\prime}$ & Isoquinoline & + \\
\hline
\end{tabular}

* Newly identified.

a Tentatively identified.

$b$ In the cases of two peaks overlapping in Fig. 2 and Fig. 3-A (or Fig. 3-B), peak numbers are marked with superscript'.

+ , trace component; ++ , minor component; +++ , major component.

though they had previously been identified in roasted food products ${ }^{16)}$ such as coffer, beef, sesame seeds, etc. All these pyridines and pyrazines are thought to be formed through Maillard reactions during the process of Katsuobushi manufacturing, especially during

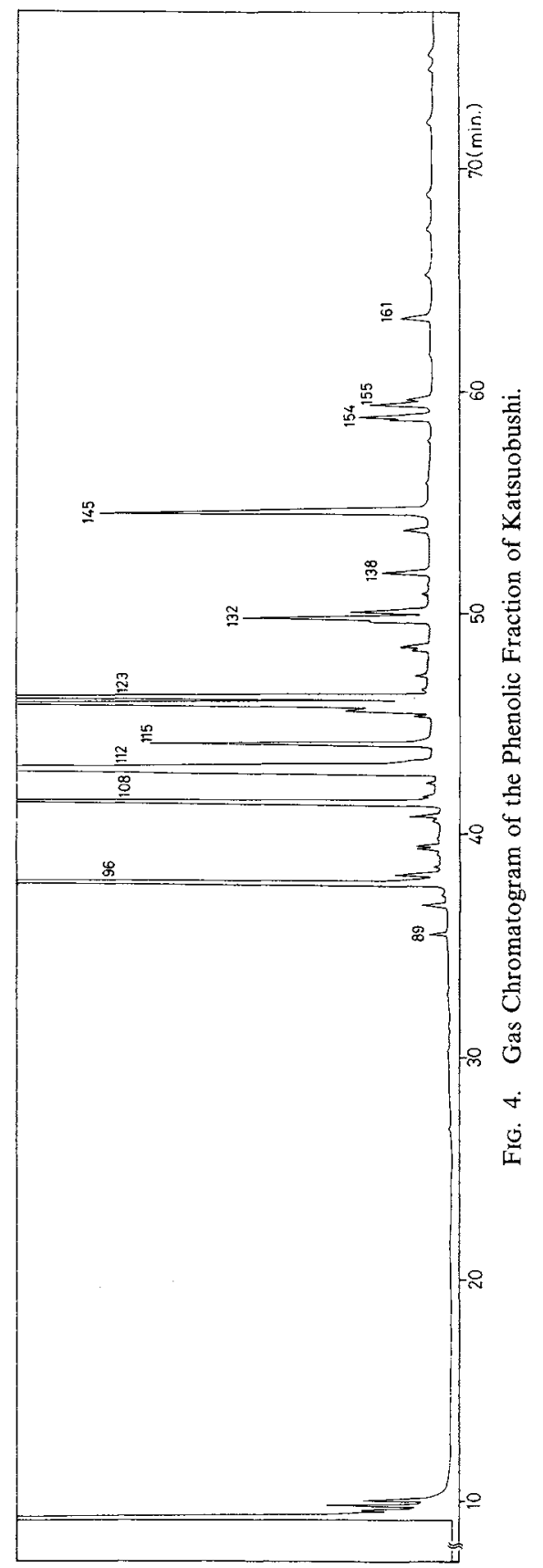


Table III. Volatile Compounds Identified from the Phenolic Fraction

\begin{tabular}{|c|c|c|}
\hline Peak No. & Compounds & Amounts \\
\hline 89 & Cyclotene & + \\
\hline 96 & Guaiacol & $+t+$ \\
\hline 103 & 2,6-Dimethylphenol & + \\
\hline 108 & 4-Methylguaiacol & +++ \\
\hline 112 & Phenol & +++ \\
\hline $112^{\prime}$ & o-Cresol & +++ \\
\hline 115 & 4-Ethylguaiacol & ++ \\
\hline $121^{*}$ & 2,5-Dimethylphenol & + \\
\hline 122 & $p$-Cresol & $++t$ \\
\hline 123 & $m$-Cresol & ++ \\
\hline $125^{\prime}$ & 4-Propylguaiacol & + \\
\hline $125^{\prime a}$ & Methyl isoeugenol(cis) & + \\
\hline $129 *$ & 2,3-Dimethylphenol & + \\
\hline $132^{\prime}$ & Eugenol & + \\
\hline 132 & 3,5-Dimethylphenol & + \\
\hline $133^{\prime}$ & 2-Ethylphenol & $+t$ \\
\hline 134 & Methyl isoeugenol(trans) & + \\
\hline 138 & 3,4-Dimethylphenol & ++ \\
\hline 142 & Isoeugenol(cis) & + \\
\hline 145 & 2,6-Dimethoxyphenol & ++ \\
\hline $154^{\prime}$ & Isoeugenol(trans) & + \\
\hline 155 & 2,6-Dimethoxy-4-methylphenol & ++ \\
\hline $155^{\prime *}$ & 4-Vinylphenol & + \\
\hline 161 & 2,6-Dimethoxy-4-ethylphenol & + \\
\hline 165 & 2,6-Dimethoxy-4-propylphenol & + \\
\hline $\begin{aligned} & * \text { Newly } \\
&{ }_{a} \text { In the } \\
& \text { Fig. } 4, \\
&+, \text { trace c } \\
& \text { major }\end{aligned}$ & $\begin{array}{l}\text { identified. } \\
\text { cases of three peaks overlapping } \\
\text { peak numbers are marked with su } \\
\text { omponent; }++, \text { minor compon } \\
\text { component. }\end{array}$ & $\begin{array}{l}\text { Fig. } 2 \text { and } \\
\text { perscript "'. } \\
\text { ent; }+++ \text {. }\end{array}$ \\
\hline
\end{tabular}

the boiling and smoking processes.

The results of exit port sniffing revealed that most of the peaks on the chromatogram possessed a fish-like or roasted odor.

\section{2) Weak acidic fraction}

The weak acidic fraction was large in quantity and had the characteristic smoky aroma of Katsuobushi. Figure 4 shows a gas chromatogram of this fraction. In the same manner as with the analysis of the basic fraction, FPD was used to confirm the existence of sulfurcontaining compounds in this fraction, but such peaks did not appear.

Table III shows the flavor compounds identified from the weak acidic fraction. Of these compounds, 2,5-dimethylphenol, 2,3-dimethylphenol and 4-vinylphenol were found in
Table IV. Volatile Compounds Identified FROM THE ACIDIC FRACTION

\begin{tabular}{llc}
\hline Peak No. & \multicolumn{1}{c}{ Compounds } & Amounts \\
\hline M 1 & Propionic acid & ++ \\
M 2 & iso-Butyric acid & ++ \\
M 3 & n-Butyric acid & +++ \\
M 5 & iso-Valeric acid & ++ \\
M 6 & n-Valeric acid & ++ \\
M 7* & iso-Hexanoic acid & ++ \\
M 8* & Tiglic acid & + \\
M 10* & n-Hexanoic acid & +++ \\
M 12* & 4-Hexenoic acid & + \\
M 14* & n-Heptanoic acid & ++ \\
M 15* & Lactic acid & + \\
M 19 & $n$-Octanoic acid & + \\
M 23* & Furoic acid & + \\
M 24* & Succinic acid & + \\
M 26* & Benzoic acid & + \\
M 30* & 5-Methyl furoic acid & + \\
M 32* & o-Toluic acid & + \\
M 33* & p-Toluic acid & + \\
M 34* & m-Toluic acid & + \\
M 35* & Phenylacetic acid & + \\
M 37* & Phenylpropionic acid & + \\
M 39 & Myristic acid & + \\
M 43 & Palmitic acid & + \\
M 44* & 9-Hexadecenoic acid & + \\
\hline
\end{tabular}

* Newly identified.

+ , trace component; ++ , minor component; +++ , major component.

Katsuobushi for the first time. It is clear that the major portion of these compounds in Table III came from the wood smoke used during the smoking process of Katsuobushi manufacturing.

It was found when sniffing at the exit port and matching the peaks on the gas chromatogram that none of the compounds individually contributed to the smoky aroma of Katsuobushi. It was, therefore, presumed that the characteristic smoky aroma of Katsuobushi is made up by the combination of various compounds found in the weak acidic fraction.

\section{3) Acidic fraction}

This fraction was small in quantity and had a pungent acidic aroma. Figure 5-A shows a gas chromatogram of the methylated acidic fraction using diazomethane. Figure 5-B 


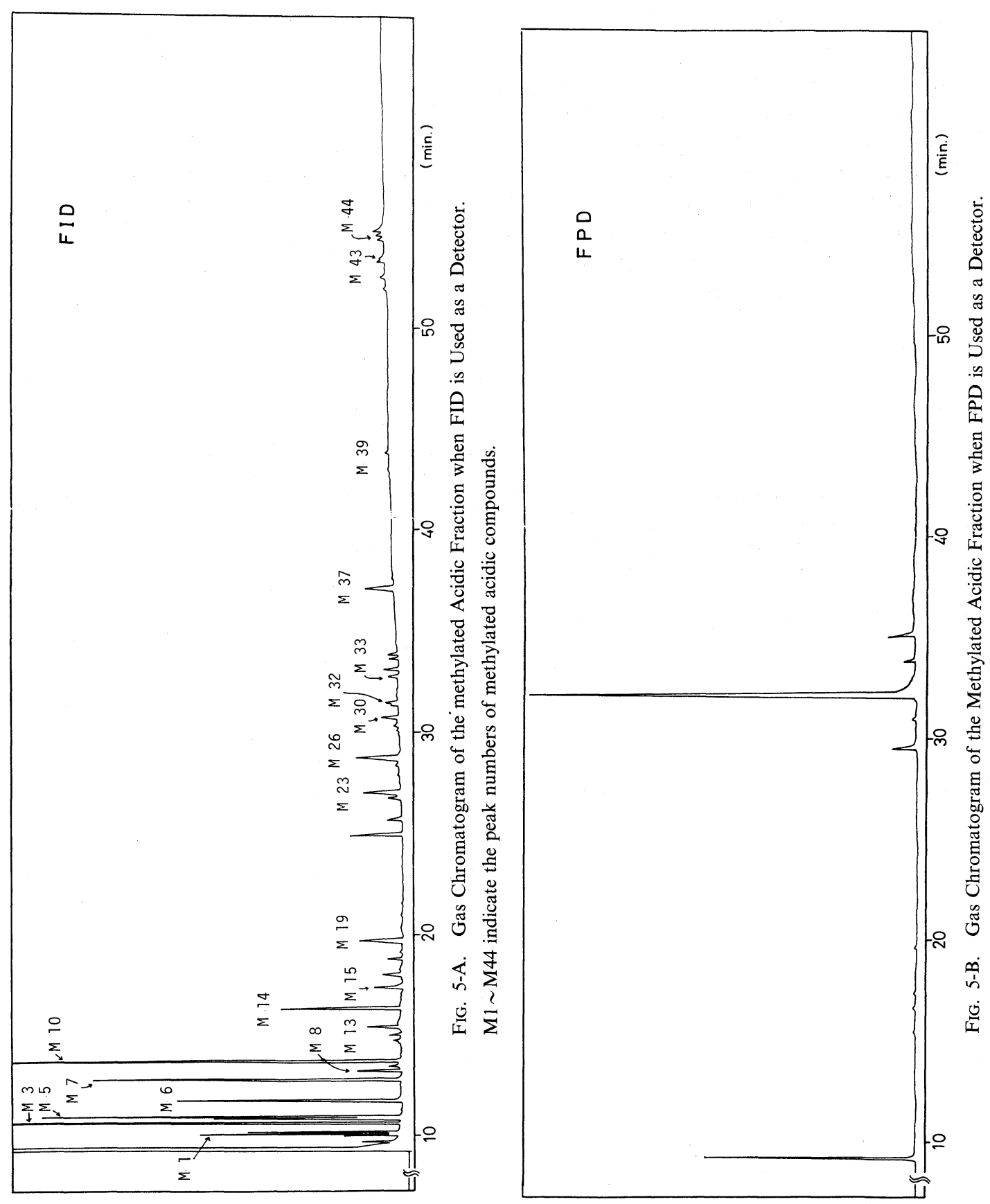


shows a gas chromatogram, when FPD was used as the detector. It clearly shows the existence of sulfur-containing compounds, but none were able to be identified due to their being so small in quantity.

The compounds identified in this acidic fraction are shown in Table IV. Of the 23 compounds identified, 15 compounds were found in Katsuobushi for the first time.

Summarizing the above findings, from the basic, weak acidic and acidic fraction of Katsuobushi, 74 flavor compounds were identified, amongst which 36 compounds were identified in Katsuobushi for the first time. As to the neutral fraction, further research is now in progress as to their olfactory contributions.

\section{REFERENCES}

1) K. Nishibori, Nippon Suisan Gakkaishi, 31, 41 (1965).

2) K. Nishibori, Nippon Suisan Gakkaishi, 31, 47 (1965).

3) K. Nishibori and K. Okamoto, Nippon Suisan Gakkaishi, 37, 156 (1971).

4) K. Nishibori and K. Okamoto, Nippon Suisan
Gakkaishi, 37, 610 (1971).

5) K. Nishibori and K. Okuyama, Nippon Suisan Gakkaishi, 38, 231 (1972).

6) K. Nishibori and K. Kasahara, Nippon Suisan Gakkaishi, 41, 1027 (1975).

7) K. Nishibori and K. Kasahara, Nippon Suisan Gakkaishi, 44, 389 (1978).

8) T. Yamanishi, A. Kobayashi, N. Nakayama and Y. Nakasone, Nippon Nôgeikagaku Kaishi, 40, 311 (1966).

9) K. Kim, T. Yamanishi, Y. Nakatani and T. Matsui, Nippon Nôgeikagaku Kaishi, 45, 328 (1971).

10) K. Hirayama and K. Ishiguro, Abstracts of Papers, Annual Meeting of the Agricultural Chemical Society of Japan, Tokyo, 1976, p. 333.

11) O. G. Vitzhum and P. Werkhoff, J. Agric. Food Chem., 23, 999 (1975).

12) N. Nunomura, M. Sasaki, $Y$. Asao and $T$. Yokotsuka, Agric. Biol. Chem., 42, 2123 (1978).

13) J. P. Walralt, A. O. Pittet, T. E. Kinlin, R. Muralidhara and A. Sanderson, J. Agric. Food Chem., 19, 972 (1971).

14) R. A. Wilson, C. J. Mussinan, I. Katz and A. Sanderson, J. Agric. Food Chem., 21, 873 (1973).

15) O. G. Vitzthum and P. Werkhoff, J. Food Sci, 39, 1210 (1974).

16) J. A. Maga and C. E. Sizer, "CRC Critical Reviews in Food Technology," 1973, p. 39. 